\title{
The first record of Rhynchitidae (Coleoptera) from Rovno amber
}

\author{
Andris Bukejs \& Andrei A. Legalov*
}

\begin{abstract}
Bukejs, A. \& Legalov, A. A. 2019: The first record of Rhynchitidae (Coleoptera) from Rovno amber. - Entomol. Fennica 30: 168-172. doi: https://doi.org/ 10.33338/ef.87173
\end{abstract}

Based on a well-preserved specimen, Pseudomesauletes groehni sp. n. is described and illustrated from Upper Eocene Rovno amber (Ukraine). It is the first fossil record of Rhynchitidae from this Lagerstätte.

A. Bukejs, Institute of Life Sciences and Technologies, Daugavpils University, Vien̄̄bas 13, Daugavpils, LV-5401, Latvia; E-mail: carabidae@inbox.lv

A. A. Legalov, Institute of Systematics and Ecology of Animals, Siberian Branch, Russian Academy of Sciences, Frunze Street, 11, Novosibirsk 630091, Russia and Tomsk State University, Lenina Prospekt 36, Tomsk 634050, Russia; *Corresponding author's e-mail:fossilweevils@gmail.com

Received 12 February 2019, accepted 13 May 2019

\section{Introduction}

Rhynchitidae is an isolated group of primitive weevils, closely related to the family Attelabidae and often considered with it in the same family (Legalov 2004, 2018). The oldest members of this family are known from the Late Cretaceous (Legalov 2015). Fossil Rhynchitidae have been described from Paleogene and Neogene impressions (Legalov 2015). Several species of the extinct genus Baltocar Kuschel, 1992 and several species of the tribes Auletini and Rhynchitini are known from Baltic amber (Voss 1953, Riedel et al. 2012, Legalov 2012, 2013, 2015).

Nine species of Curculionoidea have been described from the Rovno amber (Gratshev \& Perkovsky 2008, Petrov \& Perkovsky 2008, 2018, Nazarenko \& Perkovsky 2009, 2016, Nazarenko et al. 2011, Legalov et al. 2018, Bukejs \& Legalov 2019). No Rhynchitidae were known from this fossil resin so far.

In the present paper, a new species of the genus Pseudomesauletes Legalov, 2001 from the
Rovno amber is described. This is the first record of Rhynchitidae in the Rovno amber and Pseudomesauletina in the Eocene amber.

\section{Materials and methods}

The examined material comes from the collection of Dr. Carsten Gröhn (Glinde, Germany) and is deposited in the Centrum of Natural History (CeNak) (formerly Geological-Paleontological Institute and Museum, GPIH) of the University of Hamburg, Germany. The amber piece was polished by hand, allowing improved views of the included specimen, and was not subjected to any supplementary fixation.

Observations of this specimen were made using a Nikon $\mathrm{SMZ}^{\circledR} 745 \mathrm{~T}$ stereomicroscope. The photographs were taken using a Canon $70 \mathrm{D}^{\circledR}$ camera with a macro lens (Canon MPE-65 mm). Extended depth of field at high magnifications was achieved by combining multiple images from a range of focal planes using Helicon Fo- 
$\operatorname{cus}^{\circledR}$ v. 6.0.18 software. Measurements were taken using an ocular micrometer (expressed in millimeters).

\section{Systematic part}

Rhynchitidae Gistel, 1848

Rhynchitinae Gistel, 1848

Rhynchititae Gistel, 1848

Auletini Desbrochers des Loges, 1908

Pseudomesauletina Legalov, 2003

Pseudomesauletes Legalov, 2001

Pseudomesauletes s. str.

\section{Pseudomesauletes (Pseudomesauletes) groehni} sp. n. (Fig. 1)

Type material. Holotype: Adule female "GPIH no. 4979, coll. Gröhn no. 8590 ", deposited in CeNak; Rovno amber. A complete beetle with partially exposed metathoracic wings is included in an elongate, transparent amber piece, with the dimensions of $71 \times 29 \mathrm{~mm}$; ventral side of the specimen is obscured by "milky" opacity. Syninclusions are absent.

Type strata. Rovno amber, Upper Eocene.

Type locality. Ukraine, Rivne Oblast.

Diagnosis. The new fossil species is similar to East Asian Pseudomesauletes (Pseudomesauletes) uniformis (Roelofs, 1874) but differs in the longer rostrum, which is considerably longer than pronotum, finely punctate pronotum, and antennae inserted in basal one-third of the rostral length. Pseudomesauletes groehni sp. n. is distinguish from $P$. (P.) culex (Scudder, 1893) and $P$. (P.) ibis (Wieckham, 1912) from terminal Eocene of Florissant, in the shorter and thicker rostrum, larger eyes and smaller body size.

Description. Body: Length (without rostrum) about $3.2 \mathrm{~mm}$, rostrum length $1.2 \mathrm{~mm}$. Dark brown, antennae, legs, anterior and posterior pronotal margins and elytra paler. Sparsely covered with fine, short semirecumbent setae.

Head: Prognathous, dorsally covered with small, sparse punctation, distance between punctures about 1.0-2.0 $\times$ diameter of one puncture, ventrally with sharp transverse wrinkle; forehead wide, slightly convex; vertex slightly impressed. Rostrum long, about $8 \times$ as long as wide, $0.7 \times$ as long as pronotal length, slightly curved (in lateral view), slightly widened to apex (in dorsal view); sparsely covered with fine punctures; apparently with longitudinal carina in basal one-third of rostral length. Mandibles externally dentated. Maxillary palpi 4-articled. Gular suture single. Compound eyes large, subspherical, strongly convex. Antennae with 11 antennomeres, not geniculate, with distinct 3-segmented club; moderately long, about $1.2 \times$ as long as rostrum length, reaching middle of pronotum, inserted about in basal one-third of rostral length, sparsely covered with semierect setae; scapus subcylindrical, 1.4× as long as wide, short, $0.7 \times$ as long as antennomere 2, antennomeres 3-5 elongate-oval, antennomere 3 longer than antennomere 2; antennomere 4 about $0.8 \times$ as long as antennomere 3 , antennomeres 6-8 short, slightly dilated apically, antennal club about as long as antennomeres 5-8 combined, antennomeres 9 and 10 slightly transverse, slightly dilated apically, wide, antennomere 9 about $1.5 \times$ as wide as antennomere 8 , antennomere 11 oval with tapered apex; relative length ratios of antennomeres 1-11 equal to 6-912-10-8-6-6-5-5-6-11.

Pronotum: Nearly as long as wide, widest medially, slightly narrowed posteriad and anteriad; densely covered with fine punctation (punctures distinctly larger and denser than punctures of head), distance between punctures less than diameter of one puncture; disc evenly convex. Prohypomera with small, dense punctation. Scutellum apparently subtriangular, small.

Elytra almost rectangular, elongated, widest behind middle, convex, not ribbed, slightly impressed medially in anterior one-third; elytral base wider than posterior pronotal margin; humeral callus weak; elytral punctation small and sparse, in basal half forming indistinct rows, intervals flat; rounded apex of elytra when both together, without large depressed spots. Epipleuron narrow.

Metaventrite and metepisternum with fine punctation.

Legs long; femora spindel-shaped, slightly flattened, covered with fine, sparse punctation; tibiae almost straight, slightly dilated distally, with fringe of dark spinula apically, lacking costate dorsal margin; tarsi long, slightly shorter than tibiae, tarsomere 1 and 2 trapezoidal, dilated 


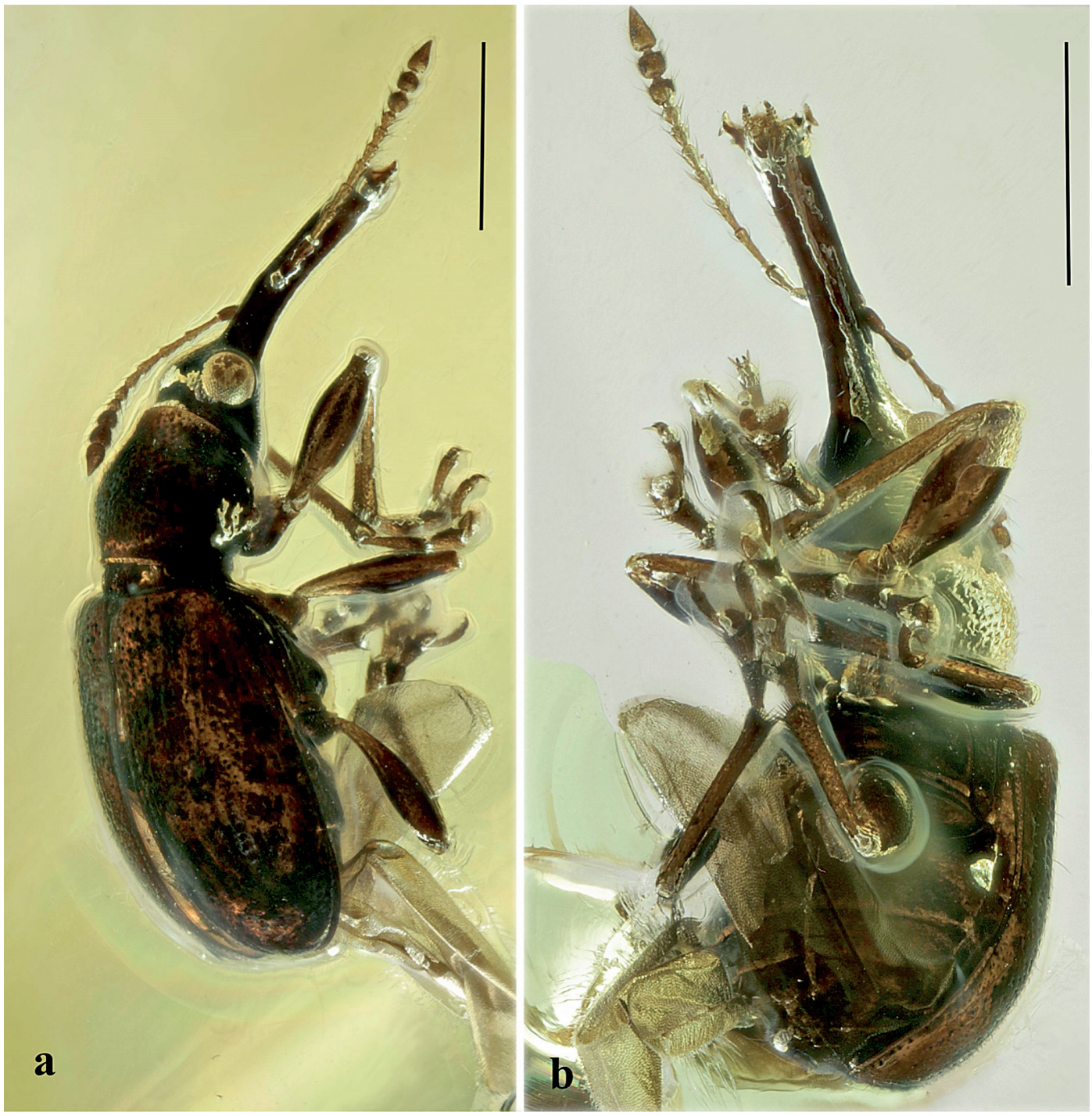

Fig. 1. Pseudomesauletes groehni sp. n., habitus of holotype. - a. Dorso-lateral view. - b. Ventral view. Scale bar $1 \mathrm{~mm}$. Photo courtesy by Jonas Damzen.

apically; tarsomere 1 not extended, tarsomere 3 deeply bilobed, terminal tarsomere elongated, subcylindrical, slightly curved; tarsal claws slightly divergent, thin, free, with long spine basally.

Abdomen. Convex, covered with fine punctation. Ventrites almost homonomous. Ventrites 1 and 2 fused. Ventrite 1 longer than ventrite 2 . Ventrite 3 shorter than ventrite 2 . Ventrites 4 and 5 subequal in length. Ventrite 4 shorter than ventrite 3.

Etymology. The species is named in honor of
Carsten Gröhn (Glinde, Germany), who provided us the species for the analysis.

Remarks. The specimen described here belongs to the family Rhynchitidae based on the not geniculate antennae, single gular suture, almost homonomous ventrites, narrow epipleuron, 4-articled maxillary palpi, fused ventrites 1 and 2 and not extended tarsomere 1 . Slightly divergent tarsal claws suggest placement in the subfamily Rhynchitinae and externally dentated mandibles in the supertribe Rhynchititae. Rounded apex of the elytra when both together confirm the assign- 
ment of the specimen to the tribe Auletini. The new species belongs to the subtribe Pseudomesauletina based on the tarsal claws with a spine, tibia lacking costate dorsal margin and antennae being inserted before middle of the rostrum. The body is covered with short sparse semirecumbent setae, elytra are not ribbed, elytral apices are without large depressed spots, antennomere 3 is longer than antennomere 2 , antennae are inserted before the middle of the rostrum and eyes are strongly convex, which suggest placement in the genus Pseudomesauletes. The specimen was assigned to the subgenus Pseudomesauletes s. str. on the basis of the almost rectangular elytra and the dark brown body coloration.

\section{Discussion}

The tribe Auletini includes the most primitive representatives of the supertribe Rhynchititae. The subtribe Pseudomesauletina includes 16 genera distributed in Eurasia, Africa, North and South America, as well as on Caribbean, Madagascar, Sunda Islands and the Philippines (Legalov 2007).

Representatives of this group are not present in the Chilean-Patagonian and Australian regions. Only two species of the genus Pseudomesauletes are known from the Paleogene (Legalov 2015). They are very similar to the extant North American Pseudomesauletes (Pseudomesauletes) ater (LeConte, 1876) and are well different from Pseudomesauletes groehni sp. n. from the Rovno amber, which is more similar to the east Palaearctic and oriental species of the genus (Pseudomesauletes uniformis (Roelofs, 1874), P. bakeri (Voss, 1922), P. gallensis Legalov, 2007, P. laosensis Legalov, 2007, P. nigrinus (Voss, 1920) and P. subpicescens (Voss, 1933)).

It can be assumed that in the Eocene the genus Pseudomesauletes was widely distributed and well differentiated. We can expect discoveries of new species in the Baltic and Oise ambers.
Acknowledgements. The authors are sincerely grateful to Dr. Carsten Gröhn (Glinde, Germany) for the loan of interesting fossil material, and to Mr. Jonas Damzen (Vilnius, Lithuania) for the permission to use his photographs. The study was partially supported by the Russian Foundation for Basic Research, project no. 19-04-00465-a and the Federal Fundamental Scientific Research Program for 2013-2020, project no. AAAA-A16-116121410121-7.

\section{References}

Bukejs A. \& Legalov, A. A. 2019: First record of the tribe Naupactini (Coleoptera: Curculionidae) in Rovno amber. - Fossil Record 22: 25-30. doi: https://doi.org/ 10.5194/fr-22-25-2019

Gratshev, V. G. \& Perkovsky, E. E. 2008: New species of the genus Glaesotropis (Insecta: Coleoptera: Anthribidae) from Rovno amber. - Paleontological Journal 42(1): 60-63. doi: https://doi.org/10.1007/s11492008-1009-8

Legalov, A. A. 2004: Reconstruction of phylogeny in leafrolling weevils (Coleoptera, Rhynchitidae, Attelabidae) using the Synap method. Report 1. - Zoologichesky Zhurnal 83(12): 1427-1432.

Legalov, A. A. 2007: Leaf-rolling weevils (Coleoptera: Rhynchitidae, Attelabidae) of the world fauna. Agro-Siberia. Novosibirsk. 523 pp.

Legalov, A. A. 2012: New Curculionoid beetles (Coleoptera: Curculionoidea) from the Baltic amber. - Paleontological Journal 46(3): 262-272. doi: https:// doi.org/10.1134/S0031030112030094

Legalov, A. A. 2013: New and little known weevils (Coleoptera: Curculionoidea) from the Paleogene and Neogene. - Historical Biology 25(1): 59-80. doi: https:// doi.org/10.1080/08912963.2012.692681

Legalov, A. A. 2015: Fossil Mesozoic and Cenozoic weevils (Coleoptera, Obrienioidea, Curculionoidea). Paleontological Journal 49(13): 1442-1513. doi: https://doi.org/10.1134/S0031030115130067

Legalov, A. A. 2018: Annotated key to weevils of the world. Part 1. Families Nemonychidae, Anthribidae, Belidae, Ithyceridae, Rhynchitidae, Brachyceridae and Brentidae. - Ukrainian Journal of Ecology 8(1): 780-831. doi: https://doi.org/10.15421/2018 280

Legalov, A. A., Nazarenko, V. Yu. \& Perkovsky, E. E. 2018: A new genus of fungus weevils (Coleoptera: Anthribidae) in Rovno amber. - Fossil Record 21: 207-212. doi: https://doi.org/10.5194/fr-21-207-2018

Nazarenko, V. Y. \& Perkovsky, E. E. 2009: A new genus and species of Dryophthorid weevils (Coleoptera, Dryophthoridae: Stromboscerinae) from the Rovno amber. - Paleontological Journal 43(9): 1097-1100. doi: https://doi.org/10.1134/S003103010909010X

Nazarenko, V. Y. \& Perkovsky E. E. 2016: A new species of Derelomine weevils (Coleoptera, Curculionidae, Curculioninae: Acalyptini) from the Rovno amber. Paleontological Journal 50(9): 991-996. doi: https:// doi.org/10.1134/S0031030116090094 
Nazarenko, V. Yu, Legalov, A. A. \& Perkovsky, E. E. 2011: A new species of the genus Caulophilus Woll. (Coleoptera: Curculionidae: Cossoninae) from the Rovno amber. - Paleontological Journal 45(3): 287-290. doi: https://doi.org/10.1134/S0031030111030105

Petrov, A. V. \& Perkovsky, E. E. 2008: New species of bark beetles (Coleoptera: Scolytidae) from the Rovno amber (Paleogene of Ukraine). - Paleontological Journal 42(4): 406-408. doi: https://doi.org/10.1134/ S0031030108040096

Petrov, A. V. \& Perkovsky, E. E. 2018: A new genus and species of Scolytinae (Coleoptera: Curculionidae) from the Rovno amber. - Paleontological Journal
52(2): 164-167. doi: https://doi.org/10.1134/ S00310 30118020090

Riedel, A., dos Santos Rolo, T., Cecilia, A. \& van de Kamp, vol. 2012: Sayrevilleinae Legalov, a newly recognised subfamily of fossil weevils (Coleoptera, Curculionoidea, Attelabidae) and the use of synchrotron microtomography to examine inclusions in amber. - Zoological Journal of the Linnean Society 165 : 773-794. doi: https://doi.org/10.1111/j.1096-3642. 2012.00825.x

Voss, E. 1953: Einige Rhynchophoren der Bernsteinfauna (Col.). - Mitteilungen des geologischen Staatsinstitutes von Hamburg 22: 119-140. [In German.] 